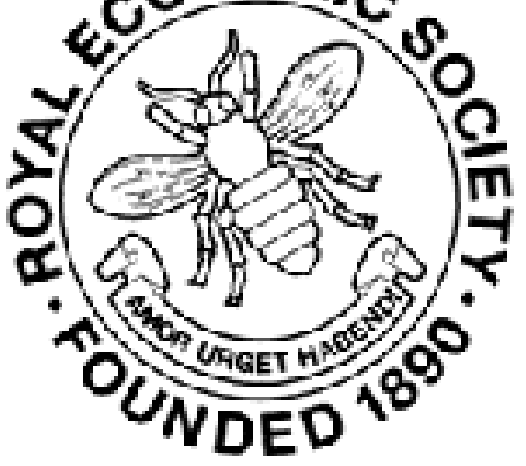

\title{
WILEY
}

Monetary Reform in the United States

Author(s): F. M. Taylor

Source: The Economic Journal, Vol. 8, No. 32 (Dec., 1898), pp. 579-586

Published by: Wiley on behalf of the Royal Economic Society

Stable URL: http://www.jstor.org/stable/2957109

Accessed: 26-06-2016 15:45 UTC

Your use of the JSTOR archive indicates your acceptance of the Terms \& Conditions of Use, available at

http://about.jstor.org/terms

JSTOR is a not-for-profit service that helps scholars, researchers, and students discover, use, and build upon a wide range of content in a trusted digital archive. We use information technology and tools to increase productivity and facilitate new forms of scholarship. For more information about JSTOR, please contact support@jstor.org.

Royal Economic Society, Wiley are collaborating with JSTOR to digitize, preserve and extend access to The Economic Journal 
is placed in the hands of the federated boards; each Brotherhood has one vote, and the vote in favour of a strike must be unanimous in order to carry. It is therefore probable that this federation of the Brotherhoods will tend rather in favour of conservatism than of radicalism.

Christabel Osborn

\section{Monetary Reform in the United States.}

IT is, probably, a familiar commonplace to the English as well as the American student of economic affairs that the monetary system of the United States stands in considerable need of reform. Doubtless matters are not quite so bad as they are often painted. The complexity which always impresses the foreign observer, accustomed as he is to a more simple and homogeneous order of things, offends the observer's sense of symmetry much more than it impairs the efficiency of the system. In like manner, the insecurity of the gold standard is commonly much exaggerated. Capital is proverbially timid, and reformers must make out a strong case to justify their existence. Further, this insecurity is hardly so much a matter of the system as of the situation. So long as there is a powerful minority opposed to the continued maintenance of the gold standard, a minority that has more than once been very near being turned into a majority, the unquestioned security of that standard is not to be expected. Nevertheless, after the utmost allowance has been made for these and other considerations, it still remains true that reform is really needed.

In the first place, it must be admitted that the standard is not as secure as it could easily be, and, hence, not as secure as it ought to be ; for a thoroughly secure standard is an indispensable condition of abiding industrial prosperity. Again, the unsatisfactoriness of the bank note system, in one particular at least, is universally conceded. It has almost no elasticity. In ordinarily prosperous years the regular autumnal demand for money to move the crops causes a decided stringency in the loan market. In the case of a panic, matters are vastly worse. During the crisis of 1893 , all parts of the country experienced a veritable monetary famine. It is probably safe to say that something like $\$ 100,000,000$ worth of non-legal money, or money substitutes, was put in circulation. ${ }^{1}$ Naturally enough, this experience led to a very great demand for what is known as an emergency circulation. A large number of people who had never before heard anything about the Suspensicn of the Bank Act of 1844, or about the "elastic limit" of the German system, came to understand the working of this expedient and clamoured for the introduction of some similar

1 I say non-legal rather than illegal, although by no means all of them could in an exact statement escape the latter designation. The need, however, was so evident and so imperative that the public was disposed to overlook the element of doubtful legality. 
element into our system. Most of the bills that are now before the country attempt in some way to meet this demand.

Another defect which all feel in the existing order of things is the lack of banking facilities for the newer or more backward districts. Doubtless this difficulty is to a certain extent due to conditions which cannot be altered-especially to the lack of capital in the districts in question. Still it is generally believed, and probably on good grounds, that more liberal banking laws would improve matters. At present, banks organised under federal laws cannot be established with less than fifty thousand dollars capital, and cannot set up branches. Hence they are not in a position to meet the needs of small communities. On the other hand, banks organised under State laws, though permitted in some States to start with almost no capital, are by the federal tax on State bank notes practically probibited from putting out circulation. But since country banking is particularly dependent for success on the power of issue, these banks also fail to satisfy the need of the small communities.

So much by way of bringing out the need of currency reform. What, now, has been done towards meeting this need? Any full answer to this question within the limits of this article is of course impossible. The briefest statement must suffice. The recognition of the need of reform dates back more than twenty-five years: the elaboration and discussion of plans, about eighteen years : the awakening of a public interest which brought reform within the range of practical politics, six or seven years. In the course of the third period, the most conspicuous episodes have been the promulgation of the so-called Baltimore plan of banking reform by the Bankers' Association in 1894, the unsuccessful attempt of Mr. Cleveland's administration to carry through a reform scheme in the winter of 1894-5, and the hard and persistent struggle of an organisation of the business men of the country known as the Indianapolis Business Men's Convention to secure a thoroughly comprehensive plan of reform. The last agitation brought about the appointment of a Commission of twelve prominent men, who, after much correspondence and discussion, recommended a detailed plan of reform, which was introduced into Congress by Representative Overstreet, and is commonly known as the Commission Bill. The new plan at once came into sharp rivalry with several bills which had been gradually evolved by members of the House Committee on Banking and Currency. Naturally the chances of passing any measure were greatly diminished by the competition of so many. At last, after much controversy, there was brought out a compromise, known as the McCleary bill, which really is a sort of combination of the most prominent of the rival schemes, viz., the Commission, the Walker and the Fowler bills. The authors of the several contributing bills, with the exception of $\mathrm{Mr}$. Walker, have acquiesced in the compromise; so that, in getting at the situation, it is hardly necessary to consider separately any other than the McCleary and Walker bills. I take 
it, then, that as good a way as any to furnish an idea of the plans before the country is to give a pretty full account of the McCleary bill, its objects and methods, and then briefly to set forth the chief points of difference between it and its principal rival, the Walker bill. Probably it has little chance of adoption. But it is entitled to the designation of being "before the country," if any scheme is ; since it has been reported by the regularly authorised committee. If it can not pass, probably no bill can.

The first thing necessary in the analysis of any project of legislation is a definite notion of the objects sought. In trying to show the need of monetary reform, we have already by implication brought out the principal objects of such legislation. Let me remind the reader that they are three: to render the standard of value more secure; to furnish a more elastic bank note system; and to supply backward districts with better banking facilities.

We proceed, then, to consider the methods proposed in the McCleary bill for giving greater security to the standard of value. In doing this, we shall find it convenient to begin with one or two remarks of a general character. In the first place, to give complete security to the standard of value is plainly to make certain that, in any contingency, twenty-five and eight-tenths grains of gold, standard fine, shall continue, as now, to fix the value of the dollar. But this, in turn, depends on its being at all times possible to convert other forms of money, or money substitutes, into gold. This possibility, finally, necessitates that some institution, public or private, shall be required to maintain a gold reserve and exchange gold against some easily available form of credit money. So, then, the first question for the legislator is, "What institution shall be chosen for this task of maintaining the ultimate reserve?" In England, as in Europe generally, it is the great central bank. With us it is the Federal Treasury. Doubtless the major part of expert opinion favours the English system. The bill before us is really a combination of the two methods. The duty of keeping the paper currency of the country convertible is, ultimately at least, to rest on the banks; while the care of silver is to devolve upon the Treasury. As the first task is much the larger, the bill may be said to decide, in a general way, for the European system; though in this country it must be many banks, rather than one, which shall undertake the task. So much being settled, the next question is, as to the method of shifting the burden from the Treasury to the banks. The natural method, and that commonly advocated, is to retire as soon as possible the legal tender demand notes, the existence of which enables the banks to put the task of keeping the reserve on the Treasury. But the presence of a very strong public sentiment against the issue of interest-bearing bonds to retire the legal tender notes, makes it incumbent on the legislator, who seriously hopes to get his bill passed, to avoid this method of attaining his goal. The McCleary bill at this point adopts a very ingenious device-taken from the bill of Representative Walker-by 
which the legal tender Treasury note is to be replaced by another almost exactly like its predecessor, except that on its back is inscribed the note of some bank which is thenceforth required to provide for its redemption in gold. To ensure this substitution'of joint Treasury and bank notes in place of Treasury notes, every bank in the system is required to buy from the Treasury with the notes of the latter an amount of the new joint notes equal to the amount of ordinary notes which the bank issues. The legal tender notes by which this process gets into the hands of the Treasury are then cancelled. Finally, provision is made for the gradual withdrawal of even these new joint notes; so that ultimately the Treasury will be relieved of all responsibility in the matter.

At this point the bill has received much criticism from Representative Walker on the ground that it does not arrange matters so as really to transfer the task of maintaining the gold reserve from the Treasury to the banks; since, although the banks are formally required to provide for the redemption of these new notes, nevertheless they are enabled to shift the burden to the Treasury by another provision of the bill, which requires the Treasury to redeem silver dollars. That is, a bank needing gold to redeem its notes, though deprived of the old endless chain made of legal tender notes, would have a new one made of silver. To this it is probably sufficient answer that the bill does not authorise the Issue Department to pay out silver except in exchange for its own certificates or gold. Consequently, silver which had once been used to draw off the Treasury's gold would thenceforth be unavailable for that purpose. Thus the endless chain would speedily disappear if the banks essayed to use it. A still further safeguard against trouble from the silver is secured by the provision that all notes under ten dollars shall be withdrawn; thus making ample room for silver, or its certificates, in the "large change" circulation.

The bill, having put the task of maintaining the convertibility of the paper money on the banks, tries to ensure that the job shall be well done by requiring the banks to keep a five per cent. reserve in gold with the Treasury, which, then, stands ready to redeem their notes whenever called upon.

We have now seen that if the McCleary bill passes, the task of maintaining the gold standard must eventually rest almost entirely on the banks. It is plain, however, that the provision requiring the current redemption of silver dollars, together with the fact that the process of getting the banks into harness is to be a gradual one, necessitates that, for a time certainly, the Treasury shall continue to have some duties in this matter. But, since under the existing organisation that department has not given complete satisfaction, some changes seemed desirable.

First, it is proposed to establish a separate department for issue and redemption, upon which shall rest all the duties which belong to the Treasury in relation to the monetary and banking system of the 
country. This department is to be under the management of three comptrollers-a device borrowed from the Fowler bill, and is to have its own funds, which must not be trenched upon to meet any financial exigencies. Secondly, new powers are given to the Secretary of the Treasury to ensure that the Issue Department shall be thoroughly equipped for its work. He is authorised to increase the already very large fund which naturally falls to the Issue Department, by transferring to it all Treasury holdings above fifty millions, also any surplus revenues which may from time to time accrue, and, in the last resort, by buying for it gold with three per cent. bonds. To ensure that the spectacle of a deficit in the general fund of the Treasury shall not shake the public confidence, and so increase the difficulties of his task, the Secretary is empowered to make short time loans to meet current expenses. ${ }^{1}$

Perhaps the worst thing which could be said against this scheme is that it is needlessly thorough. If such a reorganisation of the Treasury takes place there will be no occasion for getting the banks into the business. A Treasury organised and equipped as above outlined could easily maintain the gold standard against any attack, save an adverse decision at the polls; and against such a decision no system could avail. On the other hand, if the banks are to be required to maintain the convertibility of the note circulation, there is probably no necessity for this elaborate plan of Treasury reorganisation.

We have thus considered the methods advocated in the McCleary bill for attaining the first object of currency reform, i.e., increasing the security of the standard of value. By what means, now, does it propose to gain the second object, viz., the furnishing of an elastic note system? By an elastic note system, of course we mean one which changes in volume to correspond with the changes in the money need of the country. Plainly this includes on the one side expansibility, and on the other contractility. That the second is quite as essential as the first is a lesson which the American people find it very hard to learn. Another distinction, implied at least in most currency discussions, is ordinary elasticity and emergency elasticity. The difference is perhaps sufficiently indicated by the designations.

The McCleary bill meets the demand for emergency elasticity by subjecting one-fifth of the total amount of notes (not including the joint notes) which the banks may issue to a tax that in ordinary times would be prohibitive, i.e., six per cent. This ensures that so much, at least, would be reserved for those occasions when the need was immediate and imperative. The total volume of this circulation might reach one-fifth of the total capital of all the national banks, i.e., from one to two hundred millions of dollars. Prompt contraction after the need had passed would be ensured by the tax of one-half per cent. per

I This provision was put into the War Revenue Bill, and so is now a part of the law of the land. 
month, and by the provision that banks could escape the tax by depositing in the Treasury gold to the amount of the notes they wished to retire.

To furnish ordinary elasticity, the provisions of the McCleary bill are more elaborate. On the side of expansibility immediate gain is made by permitting banks to issue at once a circulation based on general assets equal to forty per cent. of their capital. Later, still more is gained by extending the same system to the forty per cent. of their circulation, which is at first to be based on bonds. ${ }^{1}$ Again, even that part of the circulation which is for the present based on bonds is made more expansible by having the ratio of issue to bonds raised from ninety to one hundred per cent. of the par value. To make the notes based on general assets secure, the banks are required to maintain a guarantee fund, as in the Canadian system.

On the side of contractility the bill is extremely promising. First, the whole country is to be divided into clearing-house districts, and each bank note is to be distinctly marked as coming from some particular one of these districts. Secondly, provision for the redemption of the notes of any district must be made in the clearing-house city of that district. Finally, notes must not be paid out by any bank outside their own district, unless the bank issuing them has a redemption agency within the district in which they are paid out. Under these arrangements it seems certain that notes, whenever idle, would go home to the issuing bank with great promptness.

In order to secure the third object of currency reform, i.e., improved banking facilities in the smaller or more backward communities, the McCleary bill follows the methods of the Commission Bill. The minimum of capital for national banks is lowered from the present figure, 50,000 dollars, to 25,000, thus bringing the national system within the reach of the smaller towns. Secondly, any bank is allowed to establish branches under such rules and regulations as may be established by the comptrollers. Expert opinion favours the second plan as being both more effective. and more secure than the first.

We have, thus, summarised the chief provisions of the compromise, or McCleary bill. We must now remark briefly on the principal points of difference between it and the Walker bill, which is the only conspicuous rival that has not been retired in its favour. This bill, as respects its methods of dealing with the gold standard, differs from the McCleary bill principally in that it provides for the immediate and complete assumption by the banks of the task of maintaining the gold reserve. To shift the care of the legal tender notes from the Treasury to the banks it employs the same device that is used in the McCleary bill. But, unlike the latter bill, it does not provide for the exchange of gold against silver dollars; hence there is no part of the work left for the Treasury. Still further to ensure that the banks shall in no way evade their task, Mr. Walker's bill specifically requires that they shall

1 This I suppose to be the correct interpretation of the first proviso in Section 17. 
pay out the various kinds of money in such a way as to maintain the parity of all. Thus, the elaborate machinery of the McCleary bill for maintaining the gold reserve in the interim between the passage of the bill and the time when the Government notes shall be fully retired, is rendered unnecessary.

On the banking side, the Walker bill presents several important differences. To provide an emergency circulation, it authorises a special issue through clearing-house associations of legal tender notes based on approved bonds deposited with the comptroller. This promises well, but a provision to the effect that, when three hundred millions or more of United States bonds are outstanding, no others will be accepted makes the privilege almost valueless. Banks are not wont to keep on hand large amounts of United States bonds, and, in panic times, can only with difficulty get hold of them. To meet the emergency case a power of issue based on ordinary assets seems indispensable.

On the side of ordinary elasticity, this bill goes further than its rival in the use of circulation based on general assets, but otherwise it is not materially different.

One point of divergence to which Mr. Walker attaches much importance is the provision for the federation clearing-house associations into a national association with considerable powers, thus giving a certain degree of unity and coherence to the whole banking system.

In seeking to accomplish the third object of currency legislation, i.e., providing better banking facilities for the more backward districts, Mr. Walker in another bill favours the radical plan of repealing the tax of ten per cent. on the State bank issues, which tax is of course prohibitive on such issues. This plan is usually opposed as too dangerous on account of the very lax regulations as to the issue of circulating notes which still obtain in many of the States; and Mr. Walker's method of meeting this objection would not, I think, be considered adequate. If banks chartered by the State are to have the power of issue at all, it certainly should be under conditions at least as stringent as those imposed on national banks.

In concluding this brief account of monetary reform in the United States, I shall venture the assertion that no project directed to this end has at present any considerable chance of adoption. The great majority of the voters are, and always have been, indifferent on the question. A very large minority are positively hostile to most of the particular changes which are indispensable if we would make thorough work of reform. They will not hear of the direct or indirect, partial or complete, retirement of greenbacks. They are unalterably opposed to the increase of the bonded debt. They fight bitterly any provision to secure the expansibility of the currency, since this must involve an increase in the profits of national banks. On the other hand, they are equally hostile to any plan for giving contractility to the monetary system lest the banks should be enabled thereby to lock up the money 
of the nation and "crush out the life of industry in the folds of a contracting currency." A smaller but still very large group vigorously oppose any change which promises to improve matters, because such improvement would tend to perpetuate the present order. The worse the existing system works, the sooner it will be discredited. Finally, the natural friends of reform have always been, and still are, divided in counsel, and are now in addition rendered apathetic by real or apparent improvements in the situation, by the revival of business, and by the coming forward of the new questions which have grown out of the Spanish war. On the whole, therefore, it is not improbable that the very notable movement towards reform which has been so conspicuous a feature of the last few years, is destined to pass away without having accomplished any considerable change in our monetary laws. " Even in that case, however, the movement will not necessarily have been in vain. At least the business classes will have gained in aptitude to undertake the influencing of legislation. The public will have gained in the knowledge of monetary and banking matters necessary to prepare them to pass judgment upon any future project of reform. Finally, the leaders will have made, progress towards securing that definiteness and unity in idea and purpose which will be indispensable for carrying through the work of reform when at last the time shall be ripe." 1

University of Michigan.

F. M. TAYLOR

\section{Recent Parliamentary Papers.}

IN addition to the official papers which have been already noticed in the course of this year in the Economic JournaL-mostly at some length by experts - the following may be mentioned as particularly interesting to the economist.

\section{Changes in Rates of Wages and Hours of Labour in 1897. [C. 8975.]}

The net result of the changes recorded was a rise of about $£ 45,000$ a week, a gain quite inappreciable when spread over the entire wageearning population, as further appears by considering the small proportion of the work-people in each industry affected by the changes in this or preceding years.

Report by the Chief Labour Correspondent on the Strikes and Lock-outs of 1897. [C. 9012.]

The dispute in the engineering trade alone accounts for nearly 6,000,000 working days lost out of a total of about 10,000,000 in 1897 .

1 Journal of Political Economy, Vol. VI., p. 322. 